\title{
$\mathrm{Li}\left[\mathrm{Ni}_{0.8} \mathrm{Co}_{0.15} \mathrm{Al}_{0.05}\right] \mathrm{O}_{2}$ 전극의 공침 조건을 통한 구조적 변화와 전기적 특성의 향상 고찰
}

\author{
임정빈 · 손종태* \\ 충주대학교 나노고분자 공학과, 380-702, 충주시 이류면 검단리
}

(2011년 3월 30일 접수 : 2011년 5월 23일 채택)

\section{The Study on Structural Change and Improvement of Electrochemical Properties by Co-precipitation Condition of $\mathrm{Li}\left[\mathrm{Ni}_{0.8} \mathrm{CO}_{0.15} \mathrm{Al}_{0.05}\right] \mathrm{O}_{2}$ Electrode}

\author{
Jung-Bin Im and Jong-Tae Son* \\ Department of Nano Polymer Science \& Engineering, Chungju National University Chungju, Chungbuk 380-702, Korea
}

(Received March 30, 2011 : Accepted May 23, 2011)

\begin{abstract}
초 록
본 연구에서는 리튬 이차 전지의 양극 재료인 $\mathrm{Li}\left[\mathrm{Ni}_{0.8} \mathrm{Co}_{0.15} \mathrm{Al}_{0.05} \mathrm{O}_{2}\right.$ 을 공침법(co-precipitation)을 활용하여 성공적으로 합성하였다. 이때 $\mathrm{Li}\left[\mathrm{Ni}_{0.8} \mathrm{Co}_{0.15} \mathrm{Al}_{0.05}\right] \mathrm{O}_{2}$ 의 금속염 농도를 실험 변수로 하여 합성 조건을 변화 시키면서 금속염 농도 변화로 인한 전지 특성의 영향을 분석하였다. SEM (scanning electron microscope)과 XRD (X-Ray Diffraction) 분석결과 금속염의 농도(2몰/L)가 높을 경우 분말의 균일성과 구조의 결정성이 뗠어져 전지 특성이 저하되는 현상이 발생하였다. 균일성과 결정성을 향상시키기 위하여 금속염의 농도(1몰/L)를 줄여 합성 한 결과 입도의 미분이 적고 균일성이 및 구조적 결정성이 증가됨을 확인하였다. 또한 충/방전 용량, C-rate, 사이클 등 전기화학적 특성에서도 상대적으로 우수한 특성을 보였다. 이러한 측정 결과를 바탕으로 $\mathrm{Li}\left[\mathrm{Ni}_{0.8} \mathrm{Co}_{0.15} \mathrm{Al}_{0.05}\right] \mathrm{O}_{2}$ 물질의 금속염 농도에 따른 영향을 종합적으로 고찰하였다.
\end{abstract}

\begin{abstract}
Li}\left[\mathrm{Ni}_{0.8} \mathrm{Co}_{0.15} \mathrm{Al}_{0.05}\right] \mathrm{O}_{2}$ cathode material for lithium secondary battery is obtained using co-precipitation method. To determine the optimal metal solution concentration value, the CSTR coprecipitation was carried out at various concentration values $(1-2 \mathrm{~mol} / \mathrm{L})$. The surface morphology of coated samples was characterization by SEM(scanning electron microscope) and XRD (X-Ray Diffraction)analyses. Impedance analysis and cyclic voltammogram presented that internal resistance of the cell was dependent upon the concentration of metal solution. such data is very helpful in determining the optimal content of metal solution concentration to enhancing electrochemical property by adjusting powder size distribution and crystal structure.
\end{abstract}

Keyword : Lithium secondar battery, Cathode material, Co-precipitation method, $\mathrm{Li}\left[\mathrm{Ni}_{0.8} \mathrm{Co}_{0.15} \mathrm{Al}_{0.05}\right] \mathrm{O}_{2}$

*E-mail: jt1234@cjnu.ac.kr 


\section{1. 서}

리튬이차전지는 많은 용도에 폭넓게 사용되고 있으며, 가장 잘 알려진 것은 바로 자동차의 출발, 조명, 점화 즉 SLI용 전지와 비상용 및 대기용 전원장치이며, 장난감, 휴대폰, 전등, 사진, 라디오, 컴퓨터, 캠코더 등 많은 부 분에서도 이차전지가 쓰이고 있다. 최근에는 소형 이차 전지 시장이 정체되고 있는 대신 $\mathrm{HEV}$ (hybrid electric vehicle), EV (electric vehicle), Smart Grid와 같은 새로운 분야에 주로 대형 이차전지 위주로 신수요가 창출되고 있으며 이에 따라 대형 리튬 이차전지에 적합한 소재연 구가 활발히 진행되고 있다. 리튬 이차전지의 중요한 구성물질 중 하나인 양극물질은 기존의 $\mathrm{LiCoO}_{2}$ 일변도에 서 벗어나 용량이 높은 3 원계 물질 $\left(\mathrm{Li}[\mathrm{Ni}, \mathrm{Co}, \mathrm{Mn}] \mathrm{O}_{3}\right)$, 저렴한 가격의 $\mathrm{LiMn}_{2} \mathrm{O}_{4}, \mathrm{LiFePO}_{4}$ 와 같은 새로운 양극 활물질이 개발되어 상당 부분 상용화 되고 있다.,2) $\mathrm{LiCoO}_{2}$ 의 대체 재료로 $\mathrm{LiNiO}_{2}, \mathrm{LiMn}_{2} \mathrm{O}_{4}, \mathrm{LiFePO}_{4}$ 등이 재료들이 고려되어왔으나-ø) 고용량 양극물질인 $\mathrm{LiNiO}_{2}$ 의 경우, 제조상에서 발생되는 구조적인 불안정성인 문제가 있고, $\mathrm{LiMn}_{2} \mathrm{O}_{4}$ 경우, 가역 용량이 $120 \mathrm{mAh} / \mathrm{g}$ 내외로 $\mathrm{LiCoO}_{2}$ 에 비해 작고 사이클 진행에 따른 용량의 감소가 발생하며, 특히 고온에서 수명 특성이 크게 저하된다는 문제점이 있으며, $\mathrm{LiFePO}_{4}$ 는 낮은 전기 및 이온 전도도 가 걸림돌이 되고 있다. ${ }^{7}$ 현재 $\mathrm{LiCoO}_{2}$ 를 대체할 물질 중 하나인 $\mathrm{Li}\left[\mathrm{Ni}_{0.8} \mathrm{Co}_{0.15} \mathrm{Al}_{0.05}\right]$ 는 $\mathrm{a}-\mathrm{NaFeO}_{2}$ 층상 구조를 가지고 높은 리튬이온의 이동성을 가지며 가격이 상 대적으로 저렴하고 독성이 적으며 $\mathrm{LiCoO}_{2}$ 에 비해 높은 방전 용량을 가지고 있는 장점을 가지고 있다. ${ }^{8)}$ 현재까지 공침법을 사용한 $\mathrm{Li}\left[\mathrm{Ni}_{0.8} \mathrm{Co}_{0.15} \mathrm{Al}_{0.05}\right]$ 에 대한 여러 가지 연구결과가 발표되고 있으나, 합성시 금속염 농도에 따른 연구결과는 보고된 바 없다. 따라서 본 연구에서는 금속 염의 농도를 정밀하게 제어하여 $\mathrm{Li}\left[\mathrm{Ni}_{0.8} \mathrm{Co}_{0.15} \mathrm{Al}_{0.05}\right]$ 을 공침법(co-precipitation)으로 제조하고, 이를 통해 양극 활물질의 전기화학적 특성을 종합적으로 분석하였다.

\section{2. 실험방법}

본 실험에서는 $\operatorname{CSTR(Continuos~Stirring~Tank~Reactor)~}$ 를 활용하여 $\mathrm{Li}\left[\mathrm{Ni}_{0.8} \mathrm{Co}_{0.15} \mathrm{Al}_{0.05}\right] \mathrm{O}_{2}$ 분말을 공침법으로 합성하였으며, 실험변수를 금속염의 농도로 하기 위하여 반응온도, RPM, 암모니아, 수산화나트륨 양, 열처리 온도 등 다른 합성변수들은 고정시켜 제조하였다. 금속염 $\mathrm{NiSO}_{4}-6 \mathrm{H}_{2} \mathrm{O}$ (Samchun Chemical, 99+\%), $\mathrm{CoSO}_{4}-7 \mathrm{H}_{2} \mathrm{O}$ (Samchun Chemical, 99+\%), $\mathrm{Al}\left(\mathrm{NO}_{3}\right)_{3}-9 \mathrm{H}_{2} \mathrm{O}(\mathrm{DUKSAN}$ Chemical, $98+\%$ )의 농도를 1,2 몰/L로 각 실험마다 고정 시키고, 질소 분위기하에 반응기 안으로 투입하였다. 금속염과 함께 $\mathrm{NaOH}$ 용액, $\mathrm{NH}_{4} \mathrm{OH}$ 용액을 $4 \mathrm{~L}$ 반응기
에 $1 \mathrm{~L} / \mathrm{h}$ 의 속도로 정량펌프를 이용하여 연속적으로 8시 간 반응시켰다. 반응시 반응기 내부 용액의 $\mathrm{pH}(12-12.5)$, 온도 $\left(50^{\circ} \mathrm{C}\right)$ 그리고 stirring 속도 $(\mathrm{rpm}: 500)$ 로 조절하 였다. 반응완료 후 회수된 전구체 $\left(\left[\mathrm{Ni}_{0.8} \mathrm{CO}_{0.15} \mathrm{Al}_{0.05}\right](\mathrm{OH})_{2}\right.$ 는 필터링을 통해 진공오븐으로 $130^{\circ} \mathrm{C}$ 에서 건조 시킨 후 공기 분위기에서 $550^{\circ} \mathrm{C}$ 로 5 시간 1 차 열처리를 하여 $\left[\mathrm{Ni}_{0.8} \mathrm{CO}_{0.15} \mathrm{Al}_{0.05}\right] \mathrm{O}_{2}$ 로 합성하였다. 제조된 분말은 $\mathrm{Li}_{2} \mathrm{CO}_{3}$ 와 정량적인 비율로 혼합하여 $800^{\circ} \mathrm{C}$ 에서 10 시간 동안 2차 열처리를 실시하였다. 제조된 분말의 미세구조 및 결 정성의 관찰을 위해 $\mathrm{SEM}$ (Scanning Electron Microscope, Quanta 400)과 XRD(X-Ray Diffraction, Rigaku-2000)이 사용되었다. 전기화학적 측정을 위한 양전극은 $4.0 \mathrm{~g}$ 의 시료와 도전재 역할을 하는 $0.4 \mathrm{~g}$ 의 Super P black (MMM Carbon Co.), 결착재 역할을 하는 $0.5 \mathrm{~g}$ 의 polyvinyl difluoride (Aldrich), 용매인 $15 \mathrm{ml}$ 의 N-methyl2-pyrrolidone를 혼합하여 제조되었다. 제조된 슬러리 형태 의 혼합물은 소형고속혼합기 (rpm : 1000)를 사용하여 균일하게 믹싱(mixing)하였다. 이후 $\mathrm{Al}$ foil 위에 닥터 블레이드(Dr. blade)를 사용하여 후막으로 제조한 뒤 $90^{\circ} \mathrm{C}$ 온도에서 1 시간 동안 건조시켜 극판으로 제조하 였다. 제작된 극판은 다시 $100^{\circ} \mathrm{C}$ 온도의 진공오븐 속에서 24 시간 건조시켜 잔류되어 있는 용매와 수분을 완전히 제거하였다. 셀 제작을 위해 음전극으로는 리튬 호일을 사용하였으며 ethylene carbonate/dimethyl carbonate (부피비 $1: 1$ ) 용매에 $1 \mathrm{M}$ 의 $\mathrm{LiPF}_{6}$ 이 용해되어 있는 용액을 전해액으로 사용하였다. 전기화학적 특성 측정을 위한 셀(2016 type)은 글러브 박스(glove box)안에서 양전극, 음전극, 분리막, 전해액등을 조립하여 제조하였 으며 제작된 셀의 전기화학적 성질은 WonAtech사의 갈바노스테틱(galvanostatic) 충방전기(charge-discharge test system)를 이용하여 측정되었다. 셀의 임피던스 측 정을 위해 Solartron사의 frequency response analyzer (Solartron 1260 in conjunction with a Solatron 1287 electrochemical interface)가 사용되었다.

\section{3. 결과 및 고찰}

Fig. 1은 금속염의 농도(1몰/L, 2몰/L)를 변수로 공 침법으로 제조된 분말의 XRD 분석 결과를 보여주고 있 다. XRD 결과를 보면 불순물이 없는 전형적인 $\mathrm{a}-\mathrm{NaFeO}_{2}$ (space group, R3m) 패턴을 나타낸다. 이 패턴에서 (003)/ (104)면의 강도비가 높을수록, (006)/(012), (018)/(110) 면이 각각 분리될수록 고결정성임을 반영하는 것으로 기존 연구자들에 의해 보고되고 있다. ${ }^{9,10)}$ 본 연구에서는 금속염의 농도가 낮을 경우(1몰/L) $(003) /(104)$ 면의 강 도비가 1.76 로 높을 $(2$ 몰/L) 경우의 1.61 보다 약 $10 \%$ 크 며, (006)/(012), (018)/(110)면이 상대적으로 잘 분리되어 


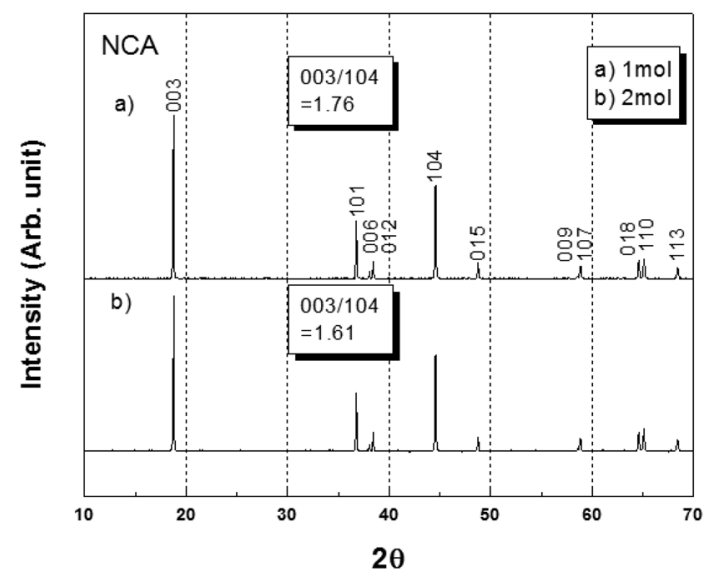

\begin{tabular}{|c|c|c|}
\hline & $\begin{array}{c}\text { lattice } \\
\text { parameter }\end{array}$ & error \\
\hline $\mathrm{a}$ & 2.8628 & 0.0001 \\
\hline $\mathrm{c}$ & 14.176 & 0.001 \\
\hline cell vol & 100.62 & 0.01 \\
\hline \multicolumn{3}{|c}{$1 \mathrm{~mol} / \mathrm{L}$} \\
\hline
\end{tabular}

$2 \mathrm{~mol} / \mathrm{L}$

\begin{tabular}{|c|c|c|}
\hline & $\begin{array}{c}\text { lattice } \\
\text { parameter }\end{array}$ & error \\
\hline $\mathrm{a}$ & 2.8649 & 0.0001 \\
\hline $\mathrm{c}$ & 14.175 & 0.001 \\
\hline cell vol & 100.76 & 0.01 \\
\hline
\end{tabular}

Fig. 1. XRD pattern of $\mathrm{Li}\left[\mathrm{Ni}_{0.8} \mathrm{Co}_{0.15} \mathrm{Al}_{0.05}\right] \mathrm{O}_{2}$ compound prepared (a) $1 \mathrm{~mol} / \mathrm{L}$; (b) $2 \mathrm{~mol} / \mathrm{L}$.

있어 결정성이 크게 증가됐음을 확인할 수 있었다. 좀 더 세밀하게 관찰하기 위하여, 격자상수값을 계산하였으나 $\mathrm{a}, \mathrm{c}$ 축의 차이가 모두 측정 편차 수준으로 확인되었다.

Fig. 2는 본 실험에서 제조된 분말의 SEM 이미지를 보여주고 있다. 금속염의 농도가 낮은 조건(1몰/L)에서 합성된 분말은 $3 \sim 5 \mu \mathrm{m}$ 정도의 크기로 균일한 구형의 모습과 1 차입자가 2 차입자 표면에 돌기모양으로 분포 되어 있어 표면적이 클 것으로 관찰되었다. 반면 금속염 의 농도가 높은 조건(2몰/L)에서 합성된 분말은 $1 \sim 10 \mu \mathrm{m}$ 정도의 크기로 불규칙한 구형의 모습과표면이 매끈한 모습으로 표면적이 작을 것으로 확인되었다. 이는 금속염 의 농도가 높을 경우 충돌회수가 많아져 표면이 다듬어 져 매끄러운 형태로 제조되며, 반응기의 내외부의 충돌 반응 기구가 달라 제조된 분말의 입도분포가 불균일한 것으로 생각된다. 표면적의 감소와 입도분포의 불균일성 은 과전압의 증가 등 전기화학적 특성 등에 나쁜 영향을 줄 수 있을 것으로 생각된다.

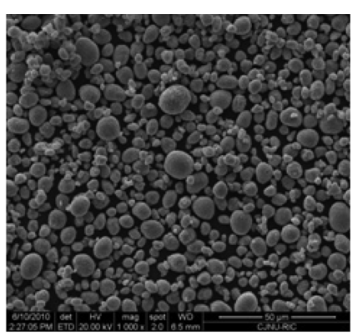

(a)

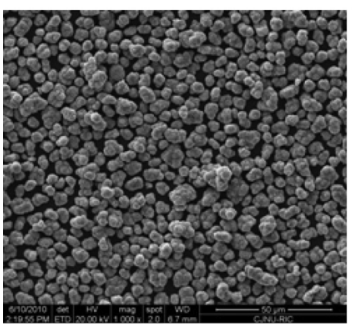

(c)

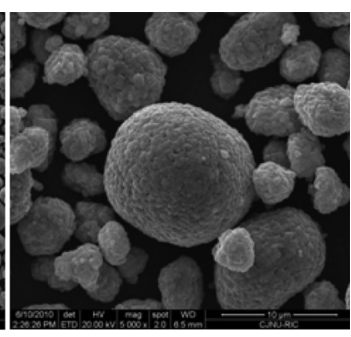

(b)

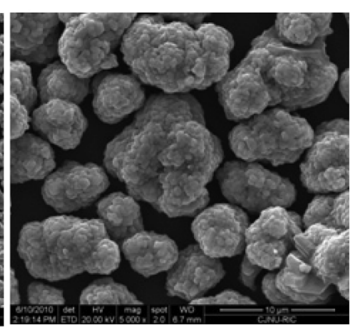

(d)
Fig. 2. SEM image of $\mathrm{Li}\left[\mathrm{Ni}_{0.8} \mathrm{Co}_{0.15} \mathrm{Al}_{0.05}\right] \mathrm{O}_{2}$ compound prepared (a) $2 \mathrm{~mol} / \mathrm{L}(\times 1000) ;$ (b) $2 \mathrm{~mol} / \mathrm{L}(\times 5000)$; (c) $1 \mathrm{~mol} / \mathrm{L}(\times 1000) ;(d) 1 \mathrm{~mol} / \mathrm{L}(\times 5000)$.

Fig. 3은 금속염의 농도를 달리하여 제조된 시료를 사용하여 제조한 양극판의 충/방전용량과 싸이클 특성을 나타내고 있다. Fig. 3(a)에서 보는 바와 같이 $85 \mathrm{~mA} / \mathrm{g}$ 의 전류밀도로 충방전시킨 경우 금속염의 농도가 낮은 조 건(1몰/L)에서 합성된 분말 시료가 높은 조건(1몰/L)에서 합성된 것 비교하여 충전량은 $16 \mathrm{mAh} / \mathrm{g}$, 방전량은 $20 \mathrm{mAh} / \mathrm{g}$ 각각 증가하였다. Fig. 3(b)의 충방전에 따른 사이클 특성도 30 회 충방전 후 기준으로 금속염의 농도 가 작은 분말 시료가 용량이 $15 \mathrm{mAh} / \mathrm{g}$ 정도 증가하였다. 앞의 SEM 이미지에서 확인했듯이 금속염의 농도가 낮은 조건(1몰/L)에서 합성한 경우 입도가 균일하고 표면적이 커 과전압이 적게 되어 용량이 증가한 것으로 판단된다. 특이한 현상은 금속염의 농도와 관계없이 $85 \mathrm{~mA} / \mathrm{g}$ 의 전류밀도에서는 매우 안정적인 사이클 특성이 관찰되었 다는 것이다. 이 부분은 전류밀도의 변화에 의한 싸이클 특성의 변화 실험 결과에서 다시 면밀히 검토를 할 예정이다.

Fig. 4는 공침법에 의해 제조된 $\mathrm{Li}\left[\mathrm{Ni}_{0.8} \mathrm{Co}_{0.15} \mathrm{Al}_{0.05}\right] \mathrm{O}_{2}$ 전극의 싸이클릭 볼타모그램(CV : Cyclic voltammogram) 이다. 일정한 주사 속도 $(0.05 \mathrm{mV} / \mathrm{sec})$ 에서 산화피크를 보 면, 금속염의 농도가 작은 분말 시료가 높은 것에 비교 하여 $0.3 \mathrm{~V}$ 전압이 감소되었다. $\mathrm{CV}$ 의 패턴에서 날카롭고 (sharp) 좁은(narrow) 피크는 고결정성임을 반영하는데, 금속염의 농도가 낮은 것이 산화 환원시 약간 날카롭고 좁으므로 상대적인 결정성이 발달하였다는 것을 알 수 있다. 상기 결과는 XRD 분석과 일치하는 결과이다. 


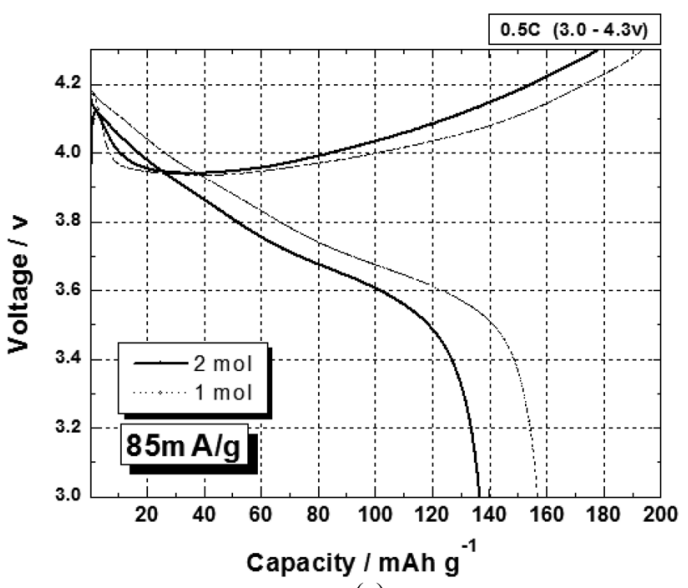

(a)

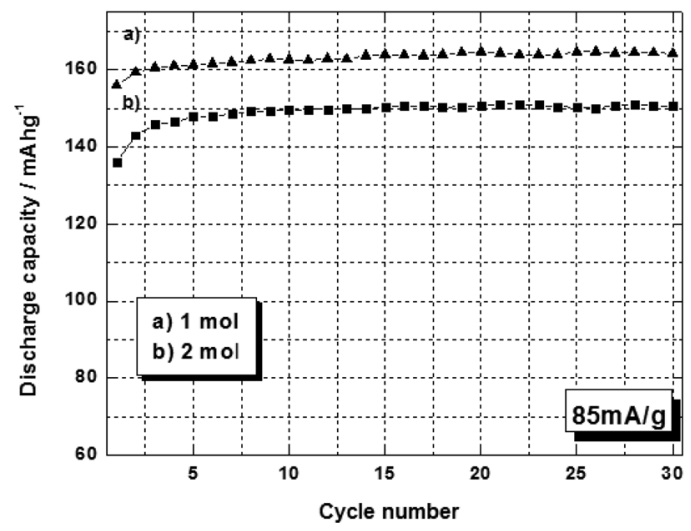

(b)

Fig. 3. a) First charge-discharge curves of $\mathrm{Li}\left[\mathrm{Ni}_{0.8} \mathrm{Co}_{0.15}\right.$ $\left.\mathrm{Al}_{0.05}\right] \mathrm{O}_{2}$ electrode. b) Cycle performance of $\mathrm{Li}\left[\mathrm{Ni}_{0.8} \mathrm{Co}_{0.15}\right.$ $\left.\mathrm{Al}_{0.05}\right] \mathrm{O}_{2}$ electrode.

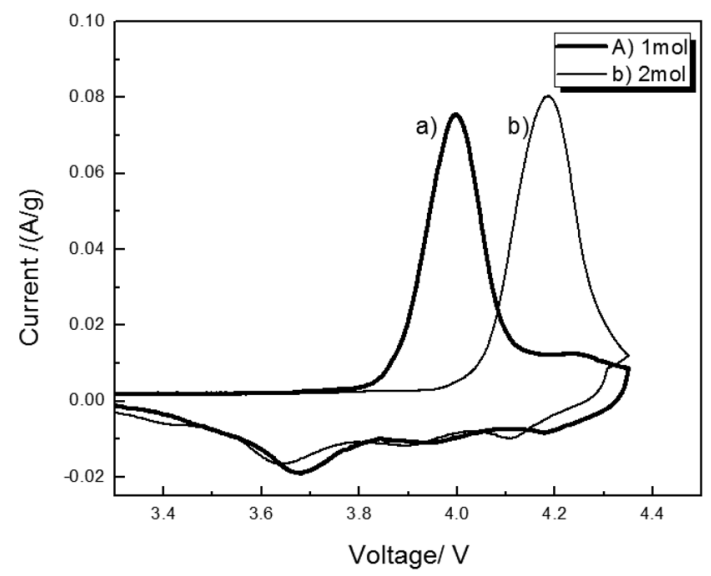

Fig. 4. Cyclic voltammogram of $\mathrm{Li}\left[\mathrm{Ni}_{0.8} \mathrm{Co}_{0.15} \mathrm{Al}_{0.05}\right] \mathrm{O}_{2}$ electrode at a scan rate of $0.05 \mathrm{mV} / \mathrm{sec}$ (a) $1 \mathrm{~mol} / \mathrm{L}$; (b) $2 \mathrm{~mol} / \mathrm{L}$.
$\mathrm{CV}$ 분석을 통해 금속염의 농도가 낮은 조건(1몰/L)에서 합성된 분말이 높은 것과 비교하여 과전압이 작고 결정 성이 발달되어 있음을 확인할 수 있었다. 특히 과전압이 낮은 극판의 경우 전류량이 클수록 용량유지 및 싸이클 특성이 향상되므로 전류량의 변화에 따른 충/방전 특성 실험을 진행하였다.

Fig. 5는 금속염 농도를 변수로 제조된 양극판의 C-rate 의 변화시 방전용량을 나타내고 있다. 고율 특성을 알아 보기 위해 전류밀도를 변수 $(0.1 \mathrm{C} \rightarrow 0.2 \mathrm{C} \rightarrow 0.5 \mathrm{C} \rightarrow$ $1 \mathrm{C} \rightarrow 2 \mathrm{C} \rightarrow 5 \mathrm{C} \rightarrow 1 \mathrm{C})$ 로 실험을 진행하였다. Fig. 3 의 $85 \mathrm{~mA} / \mathrm{g}$ 의 전류밀도에서는 싸이클 특성이 금속염 농 도와 상관없이 일정하게 유지되었으나, 전류량이 증가 될수록, 특히 $340 \mathrm{~mA} / \mathrm{g}$ 의 전류밀도에서는 금속염의 농도 가 낮은 조건(1몰/L)에서 합성된 분말 시료가 $93 \mathrm{mAh} / \mathrm{g}$ 의 방전용량을 나타내는데 비해 농도가 높은 조건(1몰/L) 에서 합성된 것은 $0 \mathrm{mAh} / \mathrm{g}$ 의 방전용량을 나타내었다. 특이한 것은, 전류밀도를 다시 $17 \mathrm{mAh} / \mathrm{g}(0.1 \mathrm{C})$ 로 하였을 때는 금속염 농도에 관계없이 초기 용량을 $100 \%$ 로 유지 하는 회복율을 나타내었다. 따라서 금속염 농도에 관계없 이 양극의 구조적인 파괴나 전해질과의 반응 등 비가역 적인 화학반응은 일어나지 않았고, 입도분포와 표면적의 변화에 따른 과전압의 변화로 고율 특성만이 변화된 것임을 알 수 있다.

Fig. 6은 금속염 농도를 변수로 제조된 양극판의 출력 특성을 살펴보기 위하여 60 초간 $2 \mathrm{~mA} / \mathrm{cm}^{2}$ 의 전류를 흘린 후 전압의 변화를 측정하여 출력 $(\mathrm{A} \Delta \mathrm{V} / \mathrm{I})$ 을 구하 였다. 금속염의 농도가 낮은 조건 $(1$ 몰/L)에서 합성된 양극 극판이 높은 조건(2몰/L)의 것보다 저항 값이 충방 전[(SOC(State of Charge), DOD(Depth of Discharge)] 영역 전반에서 $100 \sim 250 \Omega \mathrm{cm}^{2}$ 높게 나타났다. 저항값에

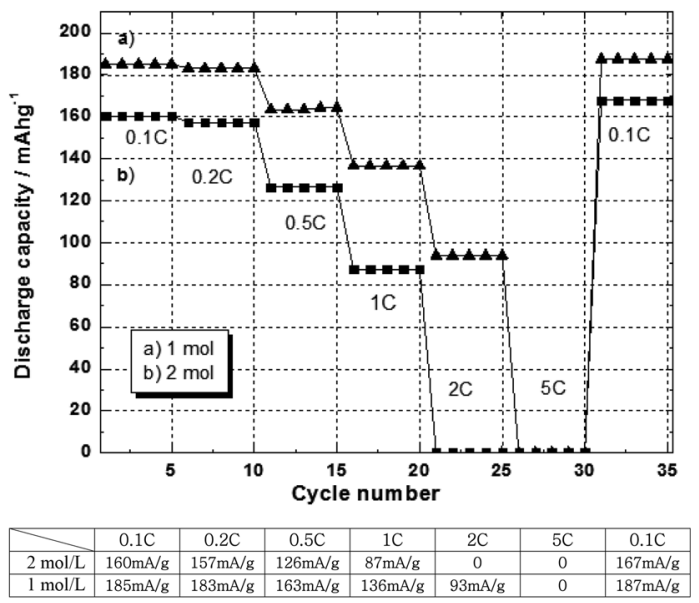

Fig. 5. Discharge capacities of $\mathrm{Li}\left[\mathrm{Ni}_{0.8} \mathrm{Co}_{0.15} \mathrm{Al}_{0.05}\right] \mathrm{O}_{2}$ electrode as a fuction of current. $(0.1 \mathrm{C}, 0.2 \mathrm{C}, 0.5 \mathrm{C}, 1 \mathrm{C}, 2 \mathrm{C}, 5 \mathrm{C})$. 

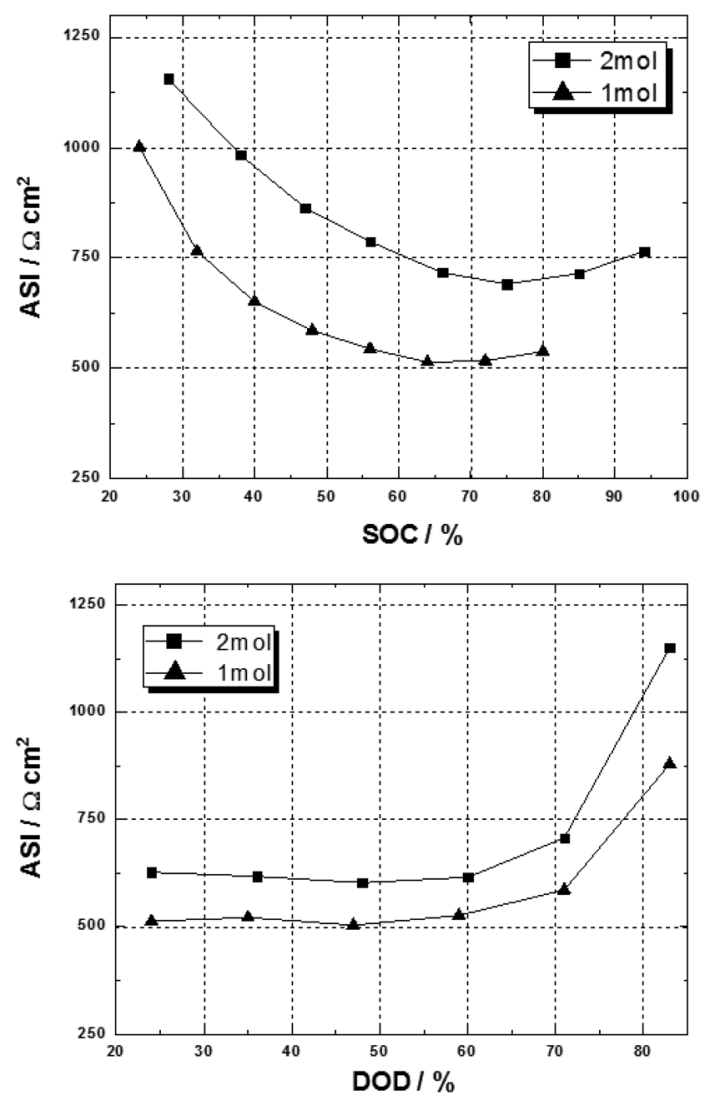

Fig. 6. Area specific impedance (ASI) of $\mathrm{Li}\left[\mathrm{Ni}_{0.8} \mathrm{Co}_{0.15} \mathrm{Al}_{0.05}\right] \mathrm{O}_{2}$ electrode as a function of state of charge and discharge.

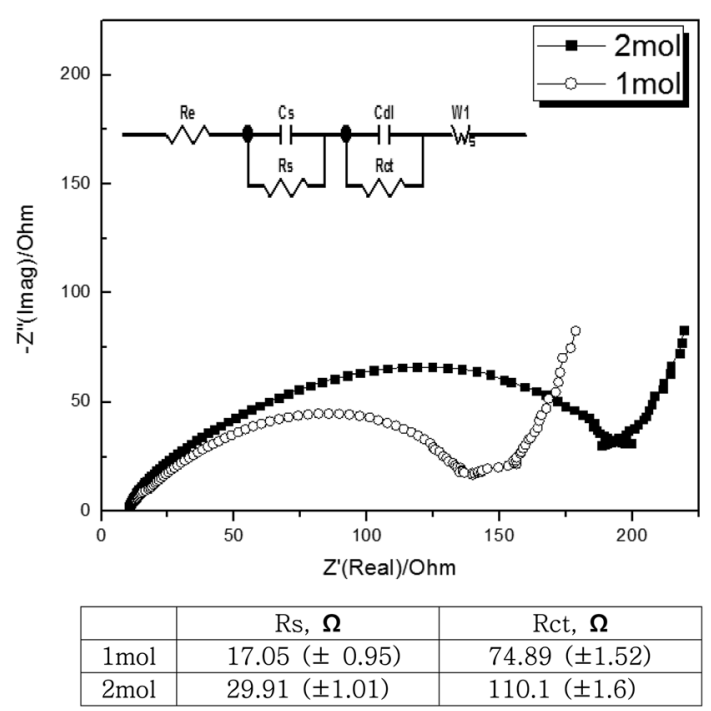

Fig. 7. The Nyquist plots of $\mathrm{Li}\left[\mathrm{Ni}_{0.8} \mathrm{Co}_{0.15} \mathrm{Al}_{0.05}\right] \mathrm{O}_{2}$ electrode.
영향을 주는 계면 반응의 변화를 더욱 자세히 분석하기 위하여 임피던스(impedance) 특성을 관찰 하였다.

Fig. 7은 금속염 농도를 변수로 제조된 양극판의 임 피던스 특성을 나타내고 있다. 금속염의 농도가 낮은 조 건(1몰/L)에서 합성된 양극이 뚜렷한 저항 감소를 보여주 고 있다. 즉 산화물 입자의 접촉저항(Rs)이 $29.91 \Omega$ 에서 $17.05 \Omega$ 으로, 전하 전달 저항(Rct)이 $110.1 \Omega$ 에서 $74.89 \Omega$ 으로 각각 감소되었다. 금속염의 농도가 높은 경우 $(2$ 몰/L) Fig. 1-2에서 살펴본 결정성 저하 및 미세구조의 불균일성 이 산화물접촉과 리튬의 전하전달에 방해가 되는 것으로 판단된다. 임피던스, 출력, 싸이클릭 볼타모그램 측정 결과를 종합해 볼 때 금속염의 농도가 낮은 조건(1몰/L) 에서 합성된 극판이 가장 낮은 내부저항을 가지고 있으 며, 이로 인해 높은 방전용량과 안정된 사이클 특성을 얻 을 수 있었던 것으로 결론지을 수 있다.

\section{4. 결 론}

본 연구에서는 공침법으로 $\mathrm{Li}\left[\mathrm{Ni}_{0.8} \mathrm{Co}_{0.15} \mathrm{Al}_{0.05}\right] \mathrm{O}_{2}$ 을 제조시 금속염 농도를 달리하여 그 전기화학적 특성을 관찰하였다. 금속염의 농도가 높은 조건(2몰/L)에서 합성 한 경우에는 결정성이 저하되고 입도분포가 불균일한 것으로 관찰되었으며, 방전용량 및 고율특성의 열화가 나타났다. 반면 금속염의 농도가 낮은 조건(1몰/L)에서 합 성한 경우에는 결정성이 증가하고 입도분포가 균일한 것으로 관찰되었으며, 향상된 방전용량과 싸이클 특성을 보여 주었다. 이는 임피던스, 출력, 싸이클릭 볼타모그램 측정에서 관찰되는 바와 같이 결정성과 미세구조의 균 일성 증가로 인해 내부저항이 감소된 것이 원인으로 생 각된다. 따라서 공침법으로 $\mathrm{Li}\left[\mathrm{Ni}_{0.8} \mathrm{Co}_{0.15} \mathrm{Al}_{0.05}\right] \mathrm{O}_{2}$ 을 제 조시 적절한 금속염의 농도는 2 몰/L로 판단된다.

\section{감사의 글}

이 연구는 2011년도 지식 경제부의 지역혁신센터사업, 한국연구재단의 지역혁신인력양성사업 및 한국연구재단 의 기초연구사업 지원(2010-3935)을 받아 수행된 것임

\section{참고문헌}

1. J. N. Reimers and J. R. Dahn, 'Electrochemical and In Situ X-Ray Diffraction Studies of Lithium Intercalation in LixCoO ${ }_{2}^{\prime}$ J. Electrochem Soc., 139, 2091 (1992).

2. M. H. Lee, Y. J. Kang, S. T. Myung, and Y. K. Sun, 'Synthetic optimization of $\mathrm{Li}\left[\mathrm{Ni}_{1 / 3} \mathrm{Co}_{1 / 3} \mathrm{Mn}_{1 / 3}\right] \mathrm{O}_{2}$ via coprecipitation' Electrochimica Acta, 50, 939 (2004).

3. J. Ying, C. Jiang, and C. Wan, 'Preparation and characterization of high-density spherical $\mathrm{LiCoO}_{2}$ cathode 
material for lithium ion batteries' J. Power Sources, 129, 264 (2004)

4. W. Ebner, D. Fouchard, and L. Xie, 'The $\mathrm{LiNiO}_{2} /$ carbon lithium-ion battery' Solid State Ionics, 69, 238 (1994).

5. J. M. Tarascon, E. Wang, F. K. Shokoohi, W. R. McKinnon, and S. Colson, 'The Spinel Phase of $\mathrm{LiMn}_{2} \mathrm{O}_{4}$ as a Cathode in Secondary Lithium Cells' J. Electrochem Soc., 138, 2859 (1991).

6. S. W. Oh, S. T. Myung, S. M. Oh, C. S. Yoon, Khalil Amine, and Y. K. Sun, 'Polyvinylpyrrolidone-assisted synthesis of microscale C-LiFePO 4 with high tap density as positive electrode materials for lithium batteries' Electrochimica Acta, 55, 1193 (2010).

7. M. C. Gong, H. S. Kim, and B. H. Goo, 'Electrochemical properties of $\mathrm{LiFePO}_{4}$ Cathode Materials for Lithium Polymer Batteries' Journal of the korean Institute of Electrical and Electronic Material Engineers, 19, 519 (2006).
8. M. Thacheray, 'Structural considerations of layered and spinel lithiated oxides for lithium ion batteries' $J$ Electrochem Soc., 142, 2558 (1995).

9. P. Y. Liao, J. G. Duh, and H. S. Sheu, 'Structural and thermal properties of $\mathrm{LiNi}_{0.6}-\mathrm{xMgxCo}_{0.25} \mathrm{Mn}_{0.15} \mathrm{O}_{2}$ cathode materials' J. Power Sources, 183, 766 (2008).

10. S. Wu and C. W. Yang 'Preparation of $\mathrm{LiNi}_{0.8} \mathrm{Co}_{0.2} \mathrm{O}_{2}$-based cathode materials for lithium batteries by a co-precipitation method' J. Power Sources, 146, 270 (2005).

11. A. Pramanik, C. Ghanty, and S. B. Majumder, 'Synthesis and electrochemical characterization of $\mathrm{xLi}\left(\mathrm{Ni}_{0.8} \mathrm{Co}_{0.15} \mathrm{Mg}_{0.05}\right) \mathrm{O}_{2}-(1-\mathrm{x}) \mathrm{Li}\left[\mathrm{Li}_{1 / 3} \mathrm{Mn}_{2 / 3}\right] \mathrm{O}_{2} \quad(0.0 \leq \mathrm{x} \leq$ 1.0) cathodes for Li rechargeable batteries' Solid State Sciences, 12, 1797 (2010).

12. Y. J. Park, 'Stability of $\mathrm{Li}\left[\mathrm{Co}_{0.1} \mathrm{Ni}_{0.15} \mathrm{Li}_{0.2} \mathrm{Mn}_{0.55}\right] \mathrm{O}_{2}$ Cathode Material for Lithium Secondary Battery' Journal of the korean Institute of Electrical and Electronic Material Engineers, 20, 443 (2007). 